\title{
The Role of Social Entrepreneurship in Poverty Reduction
}

\author{
DR. FAHAD SULTAN \\ Assistant Professor, Institute of Business Studies and Leadership \\ Abdul Wali Khan University Mardan \\ fahadsultan@awkum.edu.pk \\ JUNAID AHMAD \\ MBA Research Scholar, Institute of Business Studies and Leadership \\ Abdul Wali Khan University Mardan \\ junaid.raees.7@gmail.com \\ ASAD SARFARAZ KHAN \\ Lecturer and PhD Scholar, Institute of Business Studies and Leadership \\ Abdul Wali Khan University Mardan \\ Asad_as2002@awkum.edu.pk \\ RAZA UR RAHMAN \\ PhD Scholar, Institute of Business Studies and Leadership \\ Abdul Wali Khan University Mardan \\ razaawkum@gmail.com
}

\begin{abstract}
The key aim of the study was to investigate the role of social entrepreneurship in poverty alleviation in district Mardan. The researcher studied previous investigations, associated with this study earlier while adopting the study method. To find out the specific objectives of the study, the researcher followed quantitative method, based on the past study of Chebbi (2016), and data was collected through questionnaire. The questionnaire was a developed questionnaire from the study of Ali and Ali, (2013).The questionnaire was distributed to 200 social entrepreneurs providing their services in different local and international NGOs, social welfare foundations operating in district Mardan. In response, a total of 150 questionnaires were received, the response rate was $75 \%$. It is a good response rate. In which $68.7 \%$ were male while the percentage of female respondents were 31.3. In which the percentage of age group under 20 were $2 \%$, from 20-30 their percentage were 64.7, while the percentage of the respondents with 31-40 age group were 16.7, and the age group from 41 to 50 their percentage were 12.7. While the age of the respondents above 50 were of $4.0 \%$.In the total 150 of the respondents, there were $55.3 \%$ single respondents while $43.7 \%$ were married respondents. Similarly, the respondents having no education or illiterate, their percentage were 0.0, while the respondents having highest school level education, there were of $4.7 \%$, and the respondents having highest college level education there percentage were 6.7, while the respondents having highest level of education were university graduate, their percentage were $87.7 \%$. Likewise, the obtained data were entered and analysed by SPSS.
\end{abstract}

Key words: Social entrepreneurship, poverty reduction. 


\section{Introduction}

The objective of social entrepreneurship is to address unfair situations characterized by the deprivation of basic needs where many governmental and philanthropic actions have fallen in producing the expected results (Daniel \& Lenain, 2014). Social entrepreneurship is an appealing tool when governmental actions have been ineffective, especially in a post-crisis situation (Daniel \& Lenain, 2014). This concept of "social entrepreneurship" combines development, through creation of sustainable jobs, and a social mission, which is to resolve social market failures (Daniel \& Lenain, 2014). The performance of social entrepreneurship is measured in the form of societal change as well as benefits done to the society (Banodia \& Dubey, 2017). Either, they may or may not earn profit, may be voluntary and working for the enablement of the weaker section of the society (Banodia \& Dubey, 2017). In the European context social entrepreneurship is devoted with greater implication (Dobele, 2012). The fact behind this greater significance may be that poverty, emigration, unemployment etc. exists in the European economy, for which innovative solutions are needed which can combine both social as well as economic benefits. In this situation of facing economic problems, the promotion of social entrepreneurship may develop a significant platform in resolving these economic problems (Dobele, 2012).

\subsection{Problem Statement}

As Pakistan is a developing country having the aggressive poverty level i.e. more than $30 \%$ of the populace are existing under the poverty line, which is almost 55 million in the year 2013 (Tahir, et al, 2016). In Khyber Pakhtunkhwa, 44\% of the populace are living under the line of poverty (Jamal, 2017). Beside this, Daniel, (2014) concluded that social entrepreneurship appears to be a suitable tool to fight against the poverty. Also from the review of previous research papers, there is also a gap exists in literature of social entrepreneurship in the perspective of district Mardan. Hence, this study will try to find out the role of social entrepreneurship in reducing poverty in district Mardan, and also try to identify government policies for promoting social entrepreneurship in Khyber Pakhtunkhwa.

\subsection{Significance of the Study}

The results of this study are expected to be useful for literature on social entrepreneurship, it will help government and policy makers in policy making; local private institutions, civil society organizations, international and local organizations, and general public in order to provide a developmental tool in the poverty reduction in the area. And also it will contribute to spread this innovative concept "the role of social entrepreneurship in poverty alleviation in district Mardan", so that some organizations can start taking conscious of its potentiality in order to experiment it. Lastly, it will help giving some concrete actions that can enable its development in the area through poverty alleviation.

\subsection{Objectives of the Study}

More specifically, we intend to achieve these objectives at the end of the study:

- To well understand the definition of the notion "social entrepreneurship".

- To investigate the role of social entrepreneurship in poverty reduction in district Mardan. 
- To identify government polices to promote social entrepreneurship in Khyber Pakhtunkhwa (supply side).

\subsection{Research Hypotheses}

- H1: Social entrepreneurship has significant role in poverty reduction in district Mardan.

- H2: Social entrepreneurship has significantly related with government policies.

\section{Literature Review}

\subsection{Definition of Social Entrepreneurship}

According to Mair and Marti (2006), a great extent of literature emphasis on explaining the notion of social entrepreneurship. Social entrepreneurship in the previous period garnered specific consideration from academics, strategy creators, general public, and practitioners (Dees, 2007). Martin and Osberg (2007) confirm that there were various researches done relating to social entrepreneurship and significant discussions have occurred over the definition of social entrepreneurship. It is key approach to challenge social changes also to react to them when the public sector and market don't (Dees, 2007). Furthermore, social enterprises and social entrepreneurs adopt innovations and solutions to unresolved social issues, keeping social value conception at the mind of their goal in order to make advantage to many persons, 'societies' as well as groups (Dees, 2007). Dees (2001), provided the key concepts regarding social entrepreneurship by believing that it consist of tracking greatly innovative tactics to solving social problems and doing so in an accountable, persistent and opportunistic manner. He also suggest that, innovative tactics are usually performed by NGOs or not-for-profits, but they may also be imitated by government agencies and also for-profits organizations (Dees, 2001).

By adding the word "social" to entrepreneurship, this means that we are evolving in a particular context which is social (Dees, 2001). The market does not perform well because it is not possible to measure properly the value creation related to social products or services (Dees, 2001). Moreover, the market does not provide the right discipline to formalize operations; some organizations ask fees for service, others receive funds and depend on the funder to orientate their actions. Consequently, few agents are involved in their production. This will contribute to the emergence of the social entrepreneur with a social, explicit and central mission (Dees, 2001). Martin and Osberg (2007) argue that the main distinction between social entrepeneurship and entrepreneurship can rely on the value proposition. Furthermore, the social entrepreneur's value intention aims to offer a service or product to those who are disadvantaged and do not have "business means or political clout to accomplish the transformative advantage on its own".

Bacq and Janssen (2011), confirm that social entrepreneurship and commercial entrepreneurship are differs from each other in two important ways: social entrepreneurship move forwards by a clear social objective, instead of income maximizing mission, while the financial income from social businesses are reinvested in the social objective rather than distributed to investors or reinvested in commercial events (Bacq \& Janssen, 2011).Social entrepreneurship can be defined as "advanced activity using specific social purpose whether in the profit making business or not-for-profit organization, or in both" (Defourny \& Nyssens, 2010). Numerous researchers delivered not a similar meanings of social entrepreneurship, which include social value and justice, practical social and economic structures, building a new balance, employing 
improvement, business talents, resolving societal issues, to social entrepreneurs as a change agent (Zahra, et al, 2009). Zahra, et al. (2009) argue that social entrepreneurship usually starts with minor, limited struggles, but generally hit social issues which have a small appearance but universal importance, like access and provision to clean water, employment, and encouraging creation of small businesses, waste controlling and poverty alleviation, etc. The innovative solutions that social entrepreneurs validate in their local context often get replicated in other geographies and can spun new global industries (Zahra, et al, 2009). Social entrepreneurship is thus having valuable consequences in the poverty reduction: creating new markets and businesses, allocating resources and authorizing new business models to neglect social problems (Harding, et al., 2006).

Social entrepreneurship refers to the practice of combining opportunity, innovation and the exploitation of the available resources to address some of the most challenging problems: economic, social, and environmental in nature (Schumpeter, 1965). As such, it is a promising approach to development work that seeks to eliminate the causes of poverty and environmental degradation (Swinburn, 2008). In order to achieve their transformational goals, social entrepreneurs start ventures that may be for-profit or nonprofit, though priority is having market-oriented activities that will generate system changes that will improve the lives of people and the planet (Swinburn, 2008).

\subsection{Definition of Poverty}

Poverty can be defined as the deficiency of basic needs of human such as clean drinking water, food, health facilities, education, shelter and sanitation, etc. (Tahir, et al, 2016). According to Chen and Ravaillon (2008), the generally applied standard in the income measure approach is 1 US\$ per day in Purchasing Power Parity 1985. According to World Bank, poverty is classified into two categories, i.e. absolute and relative poverty. At the point when poverty is said to be absolute, it shows as an absence of assets to encounter the physical requirements for living, an absence of essential security, the lack of at least one factors that empower people and groups to accept fundamental obligations and to satisfy key rights (Misango \& Ongiti, 2013). While relative poverty can be considered in connection to specific gatherings or regions in connection to the financial status of different individuals from the general public which is translated as lack of resources to reach a way of life that empowers individuals to take parts, take an interest seeing someone, and carry on with an existence that is considered normative of the general public to which they belong (Misango \& Ongiti, 2013).

Poverty is one of the key difficulties confronting developing as well as underdeveloped nations. Which is considered as normal issue comes up from the high degree of joblessness and that has turned into the main barrier of the underdeveloped and developing nations (Misango \& Ongiti, 2013). While the fact that the level and degree of poverty and joblessness has been seen to be distinctive inside and around the world and it is still remains the real obstruction to the ideal use of human resources for both social and financial advancement of the countries (Misango \& Ongiti, 2013). According to Misango and Ongiti (2013), poverty is the consequences of and also lack of not only financial capital but also lack of quality health, housing, education, employment and other connected features leading to deprivation. Moreover, the World Bank also accepted that the main causes of poverty in underdeveloped nations are political instability, lack of investment, absence of improvement in infrastructure and also lack of improvement in 
infrastructure. Pakistan is one of the developing nations confronting the extraordinary level of poverty having in excess of $33 \%$ of its people living beneath the poverty line (Jan, et al, 2009). In Pakistan, for example, the people who make wage which can't meet the day by day consumption of around 2350 calories for each individual are considered to fall under the poverty line. Furthermore, in Pakistan, training in income producing activities, absence of access to credit, fundamental social facilities and framework are basic factors behind the ingenuity of considerable poverty, particularly in under-served urban and rural zones (Jan, et al., 2009).

UNDP in its Human Development Report-2008 spots Pakistan at 136th position, among 177 developing nations of the world, the nation has in more than 2.4 million Afghan refugees (Rutherford \& Tarr, 2008). Different types of poverty win in Pakistan and more than 73 percent of the populace lives on under US\$2 every day. Pakistan, when estimated on revenue poverty, it positioned beneath than all Central Asian States and even South Asian states less Nepal and Bangladesh (Siddiqui \& Kemal, 2006). Pakistani government paid out more than 1 trillion Rupees (about $\$ 16.7$ billion) on poverty reduction agendas in the previous 5 years, cutting poverty from 35 percent in 2000-01 to 24 percent in 2006. Officially small level of financial advancement in Pakistan is additionally wrinkled in rural regions as contrast with major urban zones. Poverty line has indeed remerged to over 37\% of Pakistan's more than 16.7 billion individuals with the beginning of 2009 (Son \& Kakwani, 2008).

An investigation on poverty has took Pakistan eye to eye with a truth that it will discover hard to confess, each third Pakistani is caught in the "poor section" i.e. about in the range of 58.7 million out of an aggregate populace of 180 million live under the poverty line (Miankhail, 2009).This incorporates the greater part the populace in the remote Baluchistan, 33 percent in Sindh, 32 percent in Khyber Pakhtunkhwa and 19 percent in Punjab. The Sustainable Development Policy Institute (SDPI) study identifies the 20 poorest districts, 16 of which exist in Baluchistan and the other four poorest districts are located in Khyber Pakhtunkhwa (Miankhail, 2009). According to the survey of Ministry of Planning, Development and Reforms of Pakistan, the total population of Pakistan was 195.4 million in 2016 (Population projections for the year 2007-2030), in which Pakistan's new poverty index reveals that 4 out of 10 Pakistanis live in multidimensional poverty (Jamal, 2017). According to the methodology adopted by the Planning Commission of Pakistan for poverty estimation, 29.5 percent of the population (55 million) is estimated to live below the poverty line in the year 2013-14 (Jamal, 2017). According to the report of Dawn News (2016), says that poverty in Khyber Pakhtunkhwa stands at 49 percent, while according to the Express Tribune report (2016), poverty in Khyber Pakhtunkhwa is reducing at a very slow rate as compared to other provinces. Moreover, Khyber Pakhtunkhwa is the only province where the population living below the poverty line has increased since 2013 (Express Tribune report, 2016).

In the first MDG denotes the reduction of dangerous poverty and deprivation (Economic Review of Khyber Pakhtunkhwa, 2015-2016). Moreover, a different sources were utilized to track poverty frequency in Khyber Pakhtunkhwa in the last few years. Poverty in Khyber Pakhtunkhwa was assessed at near 29 percent in 2005-06, 7 percent higher than the national average (Economic Review of Khyber Pakhtunkhwa, 2015-2016). The difference was particularly stark when it came to urban poverty, which was recorded at a 
relatively low 13.1 percent for Pakistan as a whole, but was almost 10 percent higher for KP. The KP government estimated poverty for 2009-10, and reported it in the Comprehensive Development Strategy (CDS) as 39 in a hundred (Economic Review of Khyber Pakhtunkhwa, 2015-2016).

\subsection{Relationship between social Entrepreneurship and Poverty Reduction}

A new way of thinking about doing business or undertaking is getting more and more attention. This new approach is named social entrepreneurship (Mair \& Marti, 2006). Not only entrepreneurs, civil society, public sector are focusing attention on this concept but also the academic community is showing its growing interest with production of research paper devoted to this subject (Mair \& Marti, 2006). Formally, this movement has existed for three decades and appears to spread all around the world nowadays but still, it remains plagued by confusion. Consequently, we will examine the meaning of the two concepts, reunited in one, "entrepreneur" and "social" to come to a definition of social entrepreneurship; present the main characteristics of a social entrepreneur and identify some common pattern of functioning to social entrepreneurship (Daniel \& Lenain, 2014). Martin and Osberg (2007), stated that due to social problems the social entrepreneurship came into action, social problems may be poverty, environmental degradation, exclusion and marginalization. Moreover, in overcoming these societal issues, in the commercial or entrepreneurial context, the personalities whom utilize their creativity for fighting these like societal issues by using commercial principles with business features (Martin \& Osberg, 2007). By utilizing such commercial principles with business features in the business like background then make entrepreneurial results, i.e. social change in deprived societies. This like societal variations are the impact of social entrepreneurs in efficiency, advancing the quality of lives of the society, in addition to sustainability of societal as well as financial development (Sijabat, 2015).

Social entrepreneurship is experienced for poverty reduction, through the help of a business strategy (Diochon, 2013). "Numerous researches identified that start-up of business has a positive impression in poverty alleviation" (Ali, et al, 2017). While social entrepreneurship use an encouraging tactic for eradicating poverty's reasons, which supports in improving the economy. Furthermore, it also helps in making new organizations which might be not-for-profit or for profit, still there is requirement of regularly implementation of market oriented practices for improving the social modification which as a result improves the lives of society (Ali, et al., 2017).Social entrepreneurship has an explicit ability in the financial economic system (Dorado \& Ventresca, 2013). (Mead \& Liedholm, 1998), argue that social entrepreneurship play very crucial role in sense of raising the financial improvement as well as in lowering the poverty index in destroyed and low revenue zones of the world. The significance through social entrepreneurship in lowering the poverty as well as in rising revenue level of receivers of microcredit are at greatest satisfying (Kareem, 2015).

From the literature it clarifies that by combining both social and profitable talents and expertise in commercial and business actions, then social entrepreneurs create a massive impact in confronting the social as well as economic issues of the specific community or region and hence enable economic opportunities particularly for the poor people in the society (Sijabat, 2015). 
Granovetter (2005), confirm that the growth of social entrepreneurship helps in poverty reduction with the help of employment by creating new social enterprises and also by expanding the existing social enterprises in addition it can increase social capital by generating new social organisations, innovative initiatives for development of society, new jobs, new institutional forms, and net increases in efficiency (Granovetter, 2005).

According to White \& Fortune (2015), social entrepreneurship is now adopting different business approaches. It also links the commercial and societal actions. Furthermore, social entrepreneurship utilizes their resources, talents and skills in an entrepreneurial lens in different social problems which an underdeveloped nation can face, which may be health, education, personal and social protection, social safety, poverty reduction, social growth, ecological sustainability, and much more (White \& Fortune, 2015).

According to (Cukier, et al, 2009), social entrepreneurship has presented a universal trend which affects society by means of advanced strategies to explain social issues. Hence, Duke University's Fuqua School of Business, the CASE, i.e. Centre for the Advancement of Social Entrepreneurship, writes about social entrepreneurship that it is to identify the strengths for creating societal principles through latest innovative tactics and strategies. Furthermore, social entrepreneurs having resources of innovation, believers in efficiency and output, whom have the required skills and abilities in the professions, i.e. in business and also in social domains to advance the tactics and policies for getting the highest and effective results in the form of societal impact (Cukier, et al, 2009). The individual having this type of social mind setup can survive in all varieties of organizations: not-forprofit, for-profit, and hybrid, small and large; new and old; secular and religious, etc. (Cukier, et al., 2009).

Social entrepreneurship has profound consequences in the fast rising numeral of organizations that have generated representations of proficiently providing the access to fundamental human needs that current institutions and markets have failed to fulfil their needs (Cukier, et al, 2009). Furthermore, social entrepreneurship combines the resourcefulness of traditional entrepreneurship with an objective to change society (Cukier, et al, 2009). Moreover, social entrepreneurship offers visions that might motivate plans for more socially satisfactory and sustainable commercial approaches and organizational forms, because, it contributes directly to universally identify sustainable expansion objectives, social entrepreneurship may also inspire reputable organisations to take on better social responsibility (Cukier, et al., 2009).

At last, social entrepreneurship concretes the technique to a future that can let upcoming age groups to fulfil their necessities superior than we are able to fulfil smoothly the elementary essentials of current populace (Cukier, et al, 2009). Moreover, due to this, social entrepreneurship is having deep consequences in the economic growth: authorizing fresh business models, producing new industries, and re-aiming resources to ignored social issues. The World Bank motivate social entrepreneurs by poverty-reducing plans into interact through associates which have the assets to benefit them in implementing their plans. In 2003 James Wolfensohn, World Bank's Head, granted a huge amount of US\$60 lac in seed money to be shared among 47 minor-scale, new improvement plans in 27 nations (Cukier, et al., 2009). 


\section{Research Methodology}

The present study is quantitative in nature, the survey method for data collection was used. Among Mono, Mixed and Multi methodologies the researcher has chosen the Mono method. Through reference to time horizon, the study nature is cross-sectional. In crosssectional studies, the data from defendants is gathered just on a single point in time and that is used for further investigation (Owolabi, 2003). While some studies need researchers to gather data at different periods for getting a conclusion, so if data is collected more than once from defendants, such studies are longitudinal studies (Owolabi, 2003). The participants were selected randomly and were contacted in different organizations, like social welfare foundations and charitable trusts, non-profit organizations, associations, NGOs, etc. operating in district Mardan. The organizations selected for the study are Awaz Welfare Foundation Mardan, Human \& Social Development Organization Mardan, Initiative for Development \& Empowerment, Human Development Foundation, National Rural Support Program and Markaz Islah Darul Yateem Mardan. The data was collected from the social entrepreneurs of these organizations, to have the accurate result of the role of social entrepreneurship in poverty reduction in the selected area. The participants have different demographic backgrounds and experience level.

To attain the objectives of this research, the results will be made on the findings of primary data by developing a questionnaire for collecting data from the targeted sample. The questionnaire is developed questionnaire from the study of Ali \& Ali, (2013). The questionnaire consists of 5 sections; the first section is about demographics of the respondents, the second section is about the attitude of the respondents regarding social entrepreneurship, the third section is about the attitude of the respondents regarding poverty, the forth section is about the attitude of the respondents regarding social entrepreneurship and poverty reduction and the last section is about the attitude of the respondents regarding government policies for promoting social entrepreneurship. The questionnaire relies on a five-point Likert scale, from the range 1- strongly disagree to 5strongly agree, and will be analyzed through software SPSS-16.

\section{Linear Regression Analysis and Discussion}

To investigate the role of social entrepreneurship in poverty reduction in district Mardan and to identify government policies for promoting social entrepreneurship in Khyber Pakhtunkhwa, linear regression analysis allows us to test the Models and find the impact of single Independent Variable (IV) on single Dependent Variable (DV).

To predict the value of DV (poverty reduction) based on the value of independent variable (social entrepreneurship) the following formula was designed for the Linear Regression Equation:

POV Red $_{i}=\alpha_{0}+\alpha_{1} * S E_{i}+\mu$

In the case of social entrepreneurship-poverty reduction relationship:

POV Red is denoting poverty reduction, which is also designated as dependent variable, $\alpha_{0}$ is constant term, and $\alpha_{1}$ is regression coefficient or slope while $S E_{\tilde{i}}$ is social entrepreneurship which is also independent variable of the model, while $\mu$ is representing the error term in the model.

While in case of government policies-social entrepreneurship relationship: 


$$
S E=\alpha_{0}+\alpha_{1} * \text { GovPol }+\mu
$$

$S E$ is representing social entrepreneurship, which is also the DV in the model. While $\alpha_{0}$ is constant term, and $\alpha_{1}$ is regression coefficient or slope while GovPol is denoting government policies which is also independent variable of the model, while $\mu$ is representing the error term in the model.

\subsection{Results and Discussion}

The objectives of the study was to identify the role of social entrepreneurship in poverty reduction in district Mardan and also to identify government policies for promoting social entrepreneurship in Khyber Pakhtunkhwa. For obtaining these objectives a questionnaire was distributed among 200 social entrepreneurs whose were providing their services in different social organizations like NGOs, social welfare foundations, etc. and in response we received a total number of 150 completed questionnaires which indicates that the response rate was $75 \%$.

\subsubsection{Demographic Analysis}

The study followed demographic analysis to find out the dynamics in the populace. Demographic data include gender of the respondent, age, marital status, level of education of the respondent, job title and experience in years.

Table 1: Gender of the Respondent

\begin{tabular}{llcccc}
\hline & & Frequency & Percent & Valid Percent & Cumulative Percent \\
\hline Valid & Male & 103 & 68.7 & 68.7 & 68.7 \\
& Female & 47 & 31.3 & 31.3 & 100.0 \\
& Total & 150 & 100.0 & 100.0 & \\
\hline
\end{tabular}

Table 1 represent the gender of the respondents, the total respondents for the study were 150. There were 103 male and 47 female respondents. The percentage of male respondents were 68.7 and the percentage of female respondents were 31.3.

Table 2: Age of the Respondent

\begin{tabular}{llcccc}
\hline & & Frequency & Percent & Valid Percent & Cumulative Percent \\
\hline Valid & Under 20 & 3 & 2.0 & 2.0 & 2.0 \\
& $20-30$ & 97 & 64.7 & 64.7 & 66.7 \\
& $31-40$ & 25 & 16.7 & 16.7 & 83.3 \\
& $41-50$ & 19 & 12.7 & 12.7 & 96.0 \\
& Above 50 & 6 & 4.0 & 4.0 & 100.0 \\
& Total & 150 & 100.0 & 100.0 & \\
\hline
\end{tabular}

Table 2 represent the age of the respondent in years. In total 150 respondents the age of the respondents who's age were under 20, their frequency were only 3 with percentage of 2.0. The respondents of age 20 to 30, their frequency were 97 with $64.7 \%$. While the age of the respondents between 31 and 40, their frequency were 25 with 16.7 percentage, and the age of the respondents from 41 to 50 , their frequency were 19 with $12.7 \%$, and the respondents having age more than 50 years, their frequency were 6 frequency with $4.0 \%$. 
Table 3: Marital Status of the Respondents

\begin{tabular}{llcccc}
\hline & & Frequency & Percent & Valid Percent & Cumulative Percent \\
\hline Valid & Single & 83 & 55.3 & 55.3 & 55.3 \\
& Married & 67 & 44.7 & 44.7 & 100.0 \\
& Total & 150 & 100.0 & 100.0 & \\
\hline
\end{tabular}

Table 3 represent the respondent's marital status. In total 150 respondents, the frequency of single respondents were 83 with $55.3 \%$ and the frequency for married respondents were 67 with $44.7 \%$.

Table 4: Highest Level of Education of the Respondent

\begin{tabular}{llcccc}
\hline & & Frequency & Percent & Valid Percent & Cumulative Percent \\
\hline Valid & School Level & 7 & 4.7 & 4.7 & 4.7 \\
& College Level & 10 & 6.7 & 6.7 & 11.3 \\
& University & 133 & 88.7 & 88.7 & 100.0 \\
& Graduate & 150 & 100.0 & 100.0 & \\
& Total & 150.0 & \\
\hline
\end{tabular}

Table 4 represent the respondent's highest level of education. From total 150 respondents, there were no frequency of illiterate respondent so their percentage is 0.0 . And the respondents having highest school level education were 7 with $4.7 \%$. The respondents having highest college level education were of 10 frequency with $6.7 \%$. And the frequency of university graduate respondents were of 133 with $88.7 \%$.

Table 5: Job title of the Respondent

\begin{tabular}{llcccc}
\hline & & & Valid & \\
\hline Valid & Ownequency & Percent & Percent & Cumulative Percent \\
\cline { 2 - 5 } & Manager & 11 & 7.3 & 7.3 & 7.3 \\
& Office & 48 & 32.0 & 32.0 & 39.3 \\
& Assistant/Supervisor & 91 & 60.7 & 60.7 & 100.0 \\
& Total & 150 & 100.0 & 100.0 & \\
\hline
\end{tabular}

Table 5 represent the respondent's job title. In total 150 respondents, the owner's frequency were 11 with $7.3 \%$, while the manager's frequency were 48 with $32.0 \%$ while the frequency of office assistant or supervisor were 91 with $60.0 \%$. 
Table 6: Experience of the Respondents

\begin{tabular}{llcccc}
\hline & & & Valid & \\
& & Frequency & Percent & Percent & Cumulative Percent \\
\hline \multirow{3}{*}{ Valid } & Less than 5 years & 92 & 61.3 & 61.3 & 61.3 \\
& 6-10 years & 26 & 17.3 & 17.3 & 78.7 \\
& 11-15yeasrs & 19 & 12.7 & 12.7 & 91.3 \\
More than 15 years & 13 & 8.7 & 8.7 & 100.0 \\
Total & 150 & 100.0 & 100.0 & \\
\hline
\end{tabular}

Table 6 represent the experience of the respondents. In total 150 respondents, the frequency of respondents having less than 5 years of experience were 92 with $61.3 \%$. And the frequency of respondents with experience 6 to 10 years were 26 with $17.3 \%$, and the respondents having 11 to 15 years of experience, their frequency were 19 with $12.7 \%$. And the frequency of respondents with more than 15 years of experience were 13 with $8.7 \%$.

Table 7: Model Summary ${ }^{\mathrm{b}}$

\begin{tabular}{ccccc} 
Model & $\mathrm{R}$ & R Square & Adjusted R Square & Std. Error of the Estimate \\
\hline 1 & $.601^{\mathrm{a}}$ & .361 & .356 & .28563 \\
\hline
\end{tabular}

a. Predictors: (Constant), Social Entrepreneurship

b. Dependent Variable: Poverty Reduction

Table 7 represent regression analysis, in the above table, $\mathrm{R}$ shows the value of correlation of the model. In which the value of $\mathrm{R}$ is .601 , shows the prediction quality of the dependent variable. Which shows a good relationship and prediction level. Which shows that in social entrepreneurship and poverty reduction there is $60 \%$ relationship. In the above table, the value of R Square is .361 which represents the quantity of change in the poverty reduction affected by social entrepreneurship. The value of adjusted $\mathrm{R}$ Square is .356 , which shows that $35 \%$ variation is caused by social entrepreneurship, which is also in good acceptable range.

Table 8: ANOVA ${ }^{b}$

\begin{tabular}{llrrrrr}
\hline Model & & Sum of Squares & df & Mean Square & F & Sig. \\
\hline 1 & Regression & 6.813 & 1 & 6.813 & 83.506 & $.000 \mathrm{a}$ \\
& Residual & 12.074 & 148 & .082 & & \\
& Total & 18.887 & 149 & & & \\
\hline
\end{tabular}

a. Predictors: (Constant), Social Entrepreneurship

b. Dependent Variable: Poverty Reduction

The ANOVA table 8, describes the statistical fitness and significance of the data into the regression model. In the table $8, \mathrm{~F}(1,148)=83.506$ and significance value is .000 , shows that data fits well in regression model and the independent variable is good 
and statistically significant predictors of the dependent variable i.e. poverty reduction is significantly predicted by social entrepreneurship.

Table 9: Coefficients ${ }^{\mathrm{a}}$

\begin{tabular}{|c|c|c|c|c|c|c|}
\hline \multirow{2}{*}{\multicolumn{2}{|c|}{ Model }} & \multicolumn{2}{|c|}{$\begin{array}{l}\text { Unstandardized } \\
\text { Coefficients }\end{array}$} & \multirow{2}{*}{$\begin{array}{c}\text { Standardized } \\
\text { Coefficients } \\
\text { Beta } \\
\end{array}$} & \multirow[b]{2}{*}{$\mathrm{t}$} & \multirow[b]{2}{*}{ Sig. } \\
\hline & & B & Std. Error & & & \\
\hline 1 & (Constant) & 1.622 & .251 & & 6.464 & .000 \\
\hline & $\begin{array}{l}\text { Social } \\
\text { Entrepreneurship }\end{array}$ & .593 & .065 & .601 & 9.138 & .000 \\
\hline
\end{tabular}

a. Dependent Variable: Poverty Reduction

The table 9, coefficients, shows the strength of the relationship between independent with the dependent variable. In the above table Beta value of social entrepreneurship is 1.622 with corresponding $\mathrm{t}$ value 9.138 and significance of 0.00 is statistically significant means that if there is $1 \%$ or one unit increase in social entrepreneurship then poverty reduction will increase by 0.593 units or $59.3 \%$. The model is said to be fit. The results indicated a significant positive relationship exists between poverty reduction and social entrepreneurship, and hence hypothesis "H1" is supported.

\subsubsection{Descriptive Analysis}

Table 10: Descriptive Statistics

\begin{tabular}{lccc}
\hline & Mean & Std. Deviation & N \\
\hline Poverty Reduction & 3.9047 & .35603 & 150 \\
Social Entrepreneurship & 3.8481 & .36044 & 150 \\
\hline
\end{tabular}

Table 10 shows the descriptive analysis. Which contains descriptive statistics. The study used mean to find the central point and standard deviation to find the spread and variation in the data. The above table 10 shows the value of mean and standard deviation. The values of all variables were above 3 , which shows that the mean value for all the variables were normal.

\subsubsection{Reliability Analysis}

Table 11: Reliability Statistics

\begin{tabular}{rlccc}
\hline S.No & Variable & Cronbach's Alpha & Reliable & Non-Reliable \\
\hline 1. & Social & .860 & Reliable & - \\
& Entrepreneurship & & & \\
2. & Poverty Reduction & .874 & Reliable & - \\
3. & Government Policies & .633 & Reliable & - \\
\hline
\end{tabular}

Table 11 displays Cronbach's Alpha. In the study there are three variables, i.e. social entrepreneurship, poverty reduction and government policies for promoting social entrepreneurship. For reliability finding, Cronbach Alpha was used, i.e. reliability coefficient. The value of Cronbach's alpha is between 0 and 1, in which the greater value indicates greater reliability. The Cronbach's alpha for the variables in this study are 0.860 for social entrepreneurship, 0.874 for poverty reduction and 0.633 for government 
policies for promoting social entrepreneurship. The results of reliability analysis indicates that the data is reliable, while according to Nunnally and Bernstein (1978), the minimum benchmark for social sciences must be greater than 0.60 .

Table 12: Model Summary ${ }^{b}$

\begin{tabular}{|c|c|c|c|c|c|c|c|c|c|c|}
\hline \multirow[b]{2}{*}{ Model } & \multirow[b]{2}{*}{$\mathrm{R}$} & \multirow[b]{2}{*}{ R } & \multirow[b]{2}{*}{ Adjusted } & \multicolumn{2}{|l|}{ Std. } & \multicolumn{3}{|c|}{ Change Statistics } & \multirow[b]{2}{*}{ Sig. F } & \multirow[b]{2}{*}{$\begin{array}{l}\text { Durbin- } \\
\text { Watson }\end{array}$} \\
\hline & & & & $\begin{array}{c}\text { Error of } \\
\text { the } \\
\text { Estimate }\end{array}$ & $\begin{array}{c}\text { R } \\
\text { Square } \\
\text { Change }\end{array}$ & $\begin{array}{c}\mathrm{F} \\
\text { Change }\end{array}$ & df1 & df2 & & \\
\hline 1 & $.605^{\mathrm{a}}$ & .366 & .362 & .28786 & .366 & 85.612 & 1 & 1.E2 & .000 & 1.627 \\
\hline
\end{tabular}

a. Predictors: (Constant), Promoting Policies

b. Dependent Variable: Social Entrepreneurship

Table 12 shows regression analysis, in which the $\mathrm{R}$ shows the correlational value of the model, which is .605 , shows dependent variable prediction quality. Shows a good prediction and relationship level. Representing that there is $60 \%$ relationship between government policies and social entrepreneurship. The R Square value is .366 which shows the proportion of change in the social entrepreneurship caused by the government policies. The adjusted R Square value is .362 . This explains $36 \%$ change is caused by the independent variable. The adjusted $\mathrm{R}$ Square value is also in good acceptable range.

Table 13: ANOVA $^{\mathrm{b}}$

\begin{tabular}{|c|c|c|c|c|c|c|}
\hline \multicolumn{2}{|c|}{ Model } & \multirow{2}{*}{$\begin{array}{r}\text { Sum of Squares } \\
7.094\end{array}$} & \multirow{2}{*}{$\frac{\mathrm{df}}{1}$} & Mean Square & \multirow{2}{*}{$\frac{F}{85.612}$} & \multirow{2}{*}{$\begin{array}{l}\text { Sig. } \\
.000^{\mathrm{a}}\end{array}$} \\
\hline 1 & Regression & & & 7.094 & & \\
\hline & Residual & 12.264 & 148 & .083 & & \\
\hline & Total & 19.358 & 149 & & & \\
\hline
\end{tabular}

a. Predictors: (Constant), Promoting Policies

b. Dependent Variable: Social Entrepreneurship

The ANOVA table 13, explains the statistical significance and fitness of the data into the regression model. In the above table $\mathrm{F}(1,148)=85.612$ and significance value is .000 $(p<.005)$ shows that data fits well in regression model and the independent variables are good and statistically significant predictors of the dependent variables i.e. social entrepreneurship is significantly predicted by government policies.

\section{Table 14: Coefficients ${ }^{\mathrm{a}}$}

\begin{tabular}{|c|c|c|c|c|c|c|}
\hline \multirow{2}{*}{\multicolumn{2}{|c|}{ Model }} & \multicolumn{2}{|c|}{$\begin{array}{l}\text { Unstandardized } \\
\text { Coefficients }\end{array}$} & \multirow{2}{*}{$\begin{array}{c}\text { Standardized } \\
\text { Coefficients } \\
\text { Beta } \\
\end{array}$} & \multirow[b]{2}{*}{$\mathrm{t}$} & \multirow[b]{2}{*}{ Sig. } \\
\hline & & $\mathrm{B}$ & Std. Error & & & \\
\hline 1 & (Constant) & 1.900 & .212 & & 8.973 & .000 \\
\hline & $\begin{array}{l}\text { Promoting } \\
\text { Policies }\end{array}$ & .480 & .052 & .605 & 9.253 & .000 \\
\hline
\end{tabular}

a. Dependent Variable: Social

Entrepreneurship 
The Coefficients table 14 shows the strength of the relationship between independent variable with the dependent variable. In the above table government policies Beta value is 1.900 with corresponding $t$ value 8.973 and significance of $p<.05$ is statistically significant means that if there is one unit or $1 \%$ increase in government policies then social entrepreneurship will increase by 0.446 units or $48.0 \%$. The model is said to be fit. The results indicated a significant positive relationship exists between government policies and social entrepreneurship, and hence hypothesis " $\mathrm{H} 2$ " is also supported.

Hypothesis results

\begin{tabular}{|c|c|c|}
\hline $\begin{array}{l}\text { Hypotheses } \\
\text { Number }\end{array}$ & Hypothesis Description & Model 1 \\
\hline H1.1.1 & $\begin{array}{l}\text { Social entrepreneurship has significant role in } \\
\text { poverty reduction in district Mardan. }\end{array}$ & Accepted \\
\hline H1.1.2 & $\begin{array}{l}\text { Social entrepreneurship has significantly related } \\
\text { with government policies. }\end{array}$ & Accepted \\
\hline
\end{tabular}

Analysis of models confirmed that there has a significant and positive relationship between social entrepreneurship and poverty reduction in the context of district Mardan and the analysis also confirmed the second hypothesis of the study that social entrepreneurship has significantly related with government policies and hence both of the hypothesis for the study has been accepted by the analysis.

\section{Conclusion}

In the context of district Mardan it is confirmed on the basis of analysis that social entrepreneurship has significantly and positively associated with poverty reduction and also confirmed that the promotion of social entrepreneurship is significantly related to government policies. The past studies (qualitative and quantitative) also confirmed that social entrepreneurship is a suitable tool to fight against the poverty. The quantitative study of Chebbi (2016) also concluded that social entrepreneurship has a strong positive relationship between poverty alleviation. While the qualitative studies of Daniel \& Lenain (2014) and Connor, R., Bent-Goodley, \& B.T, (2016) also concluded that social entrepreneurship has a significant role to alleviate poverty and to promote community growth.

\subsection{Practical and Policy Implication of Research:}

The uniqueness of the study recommends numerous courses of action for social organisations, NGOs, general public, government, management and policy makers. The outcomes of the study recommend that social entrepreneurs, government, NGOs ought to identify the significance of social entrepreneurship to develop strategies and tactics to alleviate poverty. The findings of this study and the previous researches in the social entrepreneurship-poverty reduction relationship confirm that social entrepreneurship is a tool to fight against poverty and to promote community growth.

\section{References}

Adekunle, I., \& Agboola, (2017). The Role of Social Entrepreneurship in Enabling Economic. International Journal of Entrepreneurial Development, Education and Science Research/IJEDESR, 4(2), 23-35. 
Ali, A., Alam, K., \& Lodhi, N. (2017). Students intentions towards entrepreneurship: Pakistani perspective. NICE Research Journal of Social Science. ISSN: 22194282, 7(14), 154-176.

Ali, D. A., \& Ali, A. Y. (2013). Entrepreneurship development and poverty reduction: Empirical survey from Somalia. American International Journal of Social Science, 2(3), 108-113.

Bacq, S., \& Janssen, F. (2011). The multiple faces of social entrepreneurship: A review of definitional issues based on geographical and thematic criteria. Entrepreneurship \& Regional Development, 23(5-6), 373-403.

Banodia, S., \& Dubey, N. (2017). Role of social entrepreneurs as social change agents: an insight. Research Journal of Management Sciences, 6(2), 19-22.

Chen, S., \& Ravallion, M. (2010). The developing world is poorer than we thought, but no less successful in the fight against poverty. The Quarterly Journal of Economics, 125(4), 1577-1625.

Cukier, W., Rodrigues, S., \& Trenholm, S. (2009). Social entrepreneurship: a content analysis. United States Association for Small Business and Entrepreneurship. Conference Proceedings (p. 776).

Daniel, M. E., \& Lenain, P. (2014). The role of social entrepreneurship in the fight against poverty, exclusion and marginalization in Haiti.

Dees. (2001). The meaning of social entrepreneurship. Duke University.

Dees, J. G. (2007). Taking social entrepreneurship seriously. Society, 44(3), 24-31.

Defourny, J., \& Nyssens, M. (2010). Conceptions of social enterprise and social entrepreneurship in Europe and the United States: Convergences and divergences. Journal of social entrepreneurship, 1(1), 32-53.

Diochon, M. (2013). Social entrepreneurship and effectiveness in poverty alleviation: A case study of a Canadian First Nations community. Journal of Social Entrepreneurship, 4(3), 302-330.

Dobele, L. (2012). Social entrepreneurship problems and solutions: a case study of Latvia. West East Journal of Social Sciences, 1(1), 11-25.

Dorado, S., \& Ventresca, M. J. (2013). Crescive entrepreneurship in complex social problems: Institutional conditions for entrepreneurial engagement. Journal of Business Venturing, 28(1), 69-82.

Granovetter, M. (2005). The impact of social structure on economic outcomes. Journal of economic perspectives, 19(1), 33-50.

Harding, A., McNamara, J., Tanton, R., Daly, A., \& Yap, M. (2006). Poverty and disadvantage among Australian children: A spatial perspective. National Centre for Social and Economic Modelling (NATSEM).

Jamal, H. (2017). Poverty and Vulnerability Estimates: Pakistan, 2016. Social Policy and Development Centre (SPDC).

Jan, D., Eberle, P. R., Jan, A., \& Ali, G. (2009). Absolute poverty in Pakistan: Where are the poor concentrated. Sarhad J. Agric, 25(2), 321-327.

Kareem, R. O. (2015). Impact of entrepreneurship on poverty alleviation. Journal of Business Administration and Education, 7(1).

Mair, J., \& Marti, I. (2006). Social entrepreneurship research: A source of explanation, prediction, and delight. Journal of world business, 41(1), 36-44. 
Martin, R. L., \& Osberg, S. (2007). Social entrepreneurship: The case for definition. Stanford: Stanford social innovation review, 5(2), 28-39.

Mead, D. C., \& Liedholm, C. (1998). The dynamics of micro and small enterprises in developing countries. World development, 26(1), 61-74.

Miankhail, S. B. (2009). Causes \& Consequences of Poverty in Pakistan. Journal of Finance and Economics, 2, 2-44.

Misango, S. B., \& Ongiti, O. (2013). Do women entrepreneurs play a role in reducing poverty? A case in Kenya. International Review of Management and Business Research, 2(1), 87-103.

Nunnally, J. C., \& Bernstein, I. H. (1978). Psychometric theory.

Owolabi, S. (2003). The adequacy of sample size in educational research.

Rutherford, T. F., \& Tarr, D. G. (2008). Poverty effects of Russia's WTO accession: Modeling "real" households with endogenous productivity effects. Journal of International Economics. 75(1), 131-150.

Schumpeter, J. A. (1965). Economic Theory and Entrepreneurial History. In: Aitken HG (ed) Explorations in enterprise. Cambridge, MA: Harvard University Press.

Siddiqui, R., \& Kemal, A. R. (2006). Remittances, trade liberalisation, and poverty in Pakistan: The role of excluded variables in poverty change analysis. The Pakistan Development Review, 383-415.

Sijabat, R. (2015). The Role of Social Entrepreneurship in Enabling Economic Opportunities for the Poor: A Synthesis of the Literature and Empirical Works. International Journal of Business and Social Science, 6(11), 35-41.

Son, H. H., \& Kakwani, N. (2008). Global estimates of pro-poor growth. World Development, 36(6), 1048-1066.

Swinburn, G. (2008). Local Economic Development: A Primer Developing and Implementing Local Economic Development Strategies and Action Plans. Washington D.C.: World Bank.

Tahir, M., Khilji, B. A., Hussain, S. W., \& Hussain, I. (2016). Impact of Punjab Rural Support Program on Poverty Alleviation: Case study of District Mandi Bahauddin. Business \& Economic Review, 8((SE)), 53-66.

White, S., \& Fortune, P. (2015). Business environment reform and poverty: Rapid evidence assessment.

Zahra, S. A., Gedajlovic, E., Neubaum, D. O., \& Shulman, J. M. (2009). A typology of social entrepreneurs: Motives, search processes and ethical challenges. Journal of business venturing, 24(5), 519-532. 